\title{
Complications during laparoscopic cholecystectomy performed due to acute cholecystitis
}

\author{
Nizamettin Kutluer, () Burhan Hakan Kanat \\ Department of General Surgery, Health Sciences University, Elazığ Fethi Sekin State Hospital, Elazığ, Turkey
}

\begin{abstract}
Introduction: Today, laparoscopic cholecystectomy is essential in the treatment of acute cholecystitis, particularly in all patients who have applied in the early period and can tolerate surgery. Although the rates of complication and conversion to open surgery tend to decrease over time with the increasing experience, they are still among the important problems today. The most important complications of laparoscopic cholecystectomy in acute cholecystitis are biliary tract injuries and bleeding. In this article, we aimed to retrospectively present the complications that we encountered in laparoscopic cholecystectomy due to acute cholecystitis.

Materials and Methods: The patients, who underwent laparoscopic cholecystectomy with the diagnosis of acute cholecystitis between March 2016 and December 2019, were retrospectively examined. The patients' age, gender, symptoms-examination findings, laboratory findings, ultrasonography findings and pathology findings were analyzed. Complications and the rate of conversion to open in surgical treatment were evaluated.

Results: Of 70 the patients included in this study, $22(31 \%)$ were male and $48(69 \%)$ were female. The ages of the patients were between $25-70$ and the mean age was $46.08 \pm 11$. Open surgery was performed in six patients (9\%). Perop-postop complications developed in three (4\%) patients in total. Conversion to open was required in one of these patients. Biliary tract injury occurred in one patient, cystic duct stump leak occurred in one patient, and choledochal stenosis occurred in one patient.

Conclusion: As a result, early laparoscopic cholecystectomy in acute cholecystitis is an acceptable treatment option with these complications and rates of conversion to open. It should be considered that complications may occur in the interim period and patients will be at a second risk due to the postponed operation. Minimal invasive methods should be preferred as much as possible with developing complications, and if necessary, support should be obtained from more experienced teams.
\end{abstract}

Keywords: Acute cholecystitis; complication; laparoscopy; treatment.

\section{Introduction}

Laparoscopic surgical procedures can today be performed in almost all hospitals and the experiences of surgeons are increasing day by day. Cholecystectomy is especially one of the laparoscopic treatments that many surgical assistants firstly learn and apply. The validity of laparoscopic cholecystectomy (LC) is today indisputable in symptomatic gallbladder stones, other benign gallbladder diseases and early stage malignancy according to certain authors. ${ }^{[1-3]}$ It is already the most common and widely applied laparoscopic intervention today. 
Acute cholecystitis is an inflammatory disease that generates urgent symptoms with exploration findings such as increased wall thickness of the gallbladder, edema and adherence of adjacent organs along with the omentum. Its most common cause is gallbladder stones. Acute cholecystitis is a serious condition and should be treated. Although laparoscopy was considered contraindicated in acute cholecystitis in the first years of laparoscopy, this opinion lost its validity in a short time. ${ }^{[3,4]}$

Today, laparoscopic cholecystectomy is essential in the treatment of acute cholecystitis particularly in all patients who have applied in the early period and can tolerate surgery. Although the rates of complication and conversion to open surgery tend to decrease over time with the increasing experience, they are still among the important problems today. The most important complications of laparoscopic cholecystectomy in acute cholecystitis are the biliary tract injuries and bleeding. ${ }^{[5,6]}$

In this article, we aimed to retrospectively present the complications that we encountered in laparoscopic cholecystectomy due to acute cholecystitis.

\section{Materials and Methods}

The patients, who underwent laparoscopic cholecystectomy with the diagnosis of acute cholecystitis between March 2016 and December 2019, were examined retrospectively. 78 patients, who received surgical treatment due to acute cholecystitis, were evaluated retrospectively after obtaining the necessary permissions from the hospital management. The patient data were accessed via computer records and patient files. Eight patients, whose data were missing or could not be reached, were excluded from the study and 70 patients were included in the study.

Diagnosis in the cases with acute cholecystitis was made by right upper quadrant pain and right subcostal tenderness, leukocytosis and radiological imaging methods. LC was applied to all patients who could tolerate surgical intervention and were not in the subacute period.

Laparoscopic cholecystectomy was performed through standard trocar entries. In the patients converted to open, the selection of incision was chosen according to the current conditions. The patients' age, gender, symptoms-examination findings, laboratory findings, ultrasonography findings and pathology findings were analyzed. Complications and the rate of conversion to open in surgical treatment were evaluated. Leukocyte height as laboratory finding $\left(>10 \times 10^{3} / \mathrm{mm}^{3}\right)$, right upper quadrant and epigastric pain as symptom, right subcostal tenderness or defence as examination finding, gallbladder wall thickness $>5 \mathrm{~mm}$ as radiological finding, presence of hydropic gallbladder, gallstones and/or pericholecystic fluid collection were accepted as significant. Bleeding, biliary leak and biliary tract injuries were accepted as complications.

\section{Results}

Of 70 patients included in the study, $22(31 \%)$ were male and $48(69 \%)$ were female. The ages of the patients were between $25-70$ and the mean age was $46.08 \pm 11.8$. Sixty five (93\%) patients had symptoms and $5(7 \%)$ patients had undefined symptoms. Similarly, 59 patients (84\%) had examination findings while 11 patients (16\%) had no positive examination finding. The mean white blood cell (WBC) number of all patients was $12.243 \pm 3.542 / \mathrm{mm}^{3}$. Leukocyte count was within normal limits in 10 patients $(14 \%)$ while it was supported by clinical laboratory findings in 60 patients $(86 \%)$. Radiology supported acute cholecystitis in $62(89 \%)$ patients while there was no finding except for gallstone in ultrasonography in 8 patients (11\%). Furthermore, two patients had sludge appearance without gallstone. Eight patients (11\%) had findings of chronic cholecystitis in the pathology evaluation while the evaluation of 1 patient was sent to an advanced center. In the remaining 61 (87\%) patients, pathology evaluation was in line with acute cholecystitis.

Open surgery was performed in six patients (9\%). While the operation was converted to open due to biliary tract injury in 1 patient, operation was converted to open in 3 patients because of insufficient exposure and 2 patients because of bleeding. Retrograde cholecystectomy was performed in the patients whose operations were converted to open due to exploration difficulty. While in one of the patients, whose operation was converted to open due to bleeding, bleeding from the gallbladder bed by suture, cystic artery bleeding was present in the other patient and hemostasis was enabled by also connecting this.

Perop-postop complications developed in $3(4 \%)$ patients in total. Conversion to open required in one of these patients (Table 1). In 1 patient, bilious fluid came from drain on the second day following the operation. This patient underwent Endoscopic Retrograde CholangioPancreaticography (ERCP) at the outside center. Cystic duct stump leak was detected. Nasobiliary drainage was placed. Eleven days later, the catheter was removed and the patient was discharged with recovery. 


\section{Table 1. Developing Complications (4\%)}

\begin{tabular}{lll} 
Patient & Complication & Treatment Method \\
\hline 1 & Biliary tract injury & Primary repair + Choledochal T-tube drainage \\
2 & Cystic duct stump leak & ERCP - Nasobiliary drainage catheter + Sphincterotomy \\
3 & Choledochal stenosis & ERCP - Sphincterotomy
\end{tabular}

ERCP. Endoscopic retrograde cholangiopancreatography.

In 1 patient, cystic duct rupture occurred during laparoscopic traction. Laparotomy was performed and injury was detected in the cystic duct choledochal junction. Choledochal repair and T-tube drainage were performed in this patient. 17 days later, the patient was discharged after removing the T-tube. In another patient, an increase was observed in bilirubin on the first day after the operation. Since the increase continued in the follow-ups of the patient, Magnetic Resonance Cholangiopancreatography (MRCP) was performed. When choledochal gallstone and stenosis were suspected in MRCP, ERCP was performed and no gallstone was detected. In the follow-ups after ERCP, bilirubin levels returned to normal. Upon no stone or stenosis detected; It was concluded that this situation may be due to edema. We thought that the sphincterotomy performed during ERCP relieved drainage and the bilirubin level decreased accordingly.

\section{Discussion}

Laparoscopic cholecystectomy is candidate to be one of the day case surgeries. It is one of the most performed operations in general surgery clinics with low complication, morbidity and mortality rates especially under elective conditions. Due to the easier access to technology and doctor, gallbladder stones are diagnosed more frequently and surgical treatment is applied. However, although the ease of diagnosis has increased, applications to hospitals due to acute cholecystitis have not decreased. ${ }^{[7]}$

As the experience of surgeons increases, the rates of complications encountered especially in laparoscopic surgery decrease. ${ }^{[5,8]}$ Moreover, it is known that if the patient is operated as soon as possible following the start of the complaints, less complication is observed in the patient. In the studies conducted, it has been reported that the operations in the first 72 hours are more comfortable in terms of the surgeon. ${ }^{[9]}$

The most important problem encountered during laparoscopic surgery in patients with acute cholecystitis is dis- section difficulty and operative complications that may occur accordingly ${ }^{[10]}$ In our series, the reason for conversion to open in 3 patients (4\%) is completely dissection difficulty and exposure deficiency. Although we converted to open due to bleeding in two patients and biliary tract injury in another patient, the main reason for all of these was that acute cholecystitis caused dissection difficulties and anatomy could not be revealed sufficiently.

In many patients with acute cholecystitis, cystic duct is shortened and approached or adhered to the main bile duct. ${ }^{[10,1]}$ This situation can lead to biliary tract injuries especially during traction such as rupture, tearing, etc. It can occasionally lead to dissection of the main biliary tract and perception as if it is the cystic duct. One of the complications in laparoscopic cholecystectomies with high morbidity is biliary tract injuries. This rate varies between $0.1 \%$ and $1 \% .^{[2,12]}$ In the cases that we examined, biliary tract injury due to traction developed in one patient and our rate was found as $1.4 \%$. This rate was in line with the literature. The factor that mostly affects the treatment success in biliary tract injuries is the location of the injury, the time of detection and the surgeon's experience. The success rate increases as the hepatobiliary surgery experience increases. Therefore, if the injury is detected in the early period and there is not enough experience, referring the patient to an advanced center will be more accurate in terms of both the patient and the surgeon. ${ }^{[6,13]}$

In cholecystectomy, there are many methods to close the cystic duct stump. Closure with metallic clip is the most commonly preferred method which we also use. These materials, which can be applied with human factor, can sometimes cut the cystic duct especially when over-tightened. Particularly in acute cholecystitis, this risk increases since the tissue is more edematous and fragile.

In a study where biliary tract injuries due to cholecystectomy were examined, cystic duct stump leak was detected after ERCP in two of twenty eight patients. In this study, as in our patient, treatment was successfully performed with 
ERCP by applying sphincterotomy and nasobilia drainage catheter. While catheter was inserted for 3 days in one patient and 7 days in the other patient in that study, it was inserted for 11 days in our patient. This duration may possibly depend on the width of the leak and the degree of inflammation. In the same study, the effectiveness of ERCP and sphincterotomy in the patients with choledochal obstruction or stenosis was emphasized. ${ }^{[14]}$

The issue of in which patients routine blood tests should be performed after cholecystectomy is controversial. There are those who state that these test should be performed in the patients with symptoms or suspected patients. There are also those who suggest routine tests. In our clinic, we look at postoperative routine blood count and biochemical tests in the patients who underwent cholecystectomy due to acute cholecystitis. We believe that we could examine our patient with high bilirubin before symptoms developed in this way.

The rates of conversion from laparoscopy to open surgery are in a wide range in the literature. While this rate varies between 1 and 15\% for elective operations, it is higher in acute cholecystitis. ${ }^{[2,12,15,16]}$ Not being able to reveal the anatomy completely, adherences, bleeding and biliary tract injuries are reported to be among the causes. In the series we present, our rate of conversion to open surgery in laparoscopic cholecystectomy in the patients with acute cholecystitis is $9 \%$.

Although laparoscopic cholecystectomy is a daily surgical operation when everything goes well under elective conditions, undesirable complications can be encountered especially in acute cholecystitis. As a result of the complication, the patient may be discharged without wearing our or unfortunately death can occur. In a study carried out in our country in 2004, five cases of laparoscopic cholecystectomy that resulted in death were examined with both medical and forensic aspects. ${ }^{[17]}$ Although this study was conducted a long time ago, the complications experienced are still valid for today.

In our study, we took only the patients that we operated on for acute cholecystitis. However, percutaneous cholecystostomy is a method that should be considered in patients with acute cholecystitis and especially high risk. Several studies have investigated the safety and efficacy of percutaneous cholecystostomy in the management of uncomplicated acute cholecystitis both as definitive therapy and as a bridge to cholecystectomy. ${ }^{[18]}$ And a lot of them have demonstrated that percutaneous cholecystostomy can serve as the definitive treatment in patients with calculous or acalculous acute cholecystitis in $30-80 \%$ of cases depending on comorbidities. ${ }^{[18,19]}$

In patients with acute cholecystitis, subtotal cholecystectomy is also an option when the risk of complications may be high during surgery and it is not desired to proceed with open surgery. Subtotal cholecystectomy may mitigate the risk of bile duct injury when dissection into the cystohepatic triangle is unsafe. ${ }^{[20,21]}$

As a result, early laparoscopic cholecystectomy in acute cholecystitis is an acceptable treatment option with these complications and rates of conversion to open. It should be considered that complications may occur in the interim period and patients will be at a second risk due to the postponed operation. Minimal invasive methods should be preferred as much as possible with developing complications and if necessary, support should be obtained from more experienced teams.

\section{Disclosures}

Ethichs Committee Approval: The study was approved by the Local Ethics Committee.

Peer-review: Externally peer-reviewed.

Conflict of Interest: None declared.

Authorship Contributions: Concept - N.K., B.H.K.; Design - N.K., B.H.K.; Supervision - N.K., B.H.K.; Materials - N.K., B.H.K.; Data collection and/or processing - N.K., B.H.K.; Analysis and/or interpretation - N.K., B.H.K.; Literature search - N.K., B.H.K.; Writing - N.K., B.H.K.; Critical review - N.K., B.H.K.

\section{References}

1. Palanisamy $S$, Patel N, Sabnis S, Palanisamy N, Vijay A, Palanivelu $P$, et al. Laparoscopic radical cholecystectomy for suspected early gall bladder carcinoma: thinking beyond convention. Surg Endosc 2016;30:2442-8. [CrossRef]

2. Janjic G, Simatovic M, Skrbic V, Karabeg R, Radulj D. Early vs. Delayed Laparoscopic Cholecystectomy for Acute Cholecystitis - Single Center Experience. Med Arch 2020;74:34-8.

3. Kossovich MA, Khrustaleva MV, Godzhello EA, Mayorova YB, Leontyeva MS. Optimal dates of surgery for acute calculous cholecystitis. [Article in Russian] Khirurgiia (Mosk) 2020;5660. [CrossRef]

4. Taviloğlu K, Günay K, Şahin A, Güloğlu R, Ertekin C. Akut Kolesistitin cerrahi tedavisinde laparoskopik yaklaşım. End Lap Ve Minimal İnvaziv Cerrahi 1996;3:36-40. 
5. Terho PM, Leppäniemi AK, Mentula PJ. Laparoscopic cholecystectomy for acute calculous cholecystitis: a retrospective study assessing risk factors for conversion and complications. World J Emerg Surg 2016;1 1:54. [CrossRef]

6. Karabulut M, Gönenç M, Alış H. Laparoskopik kolesistektomiye bağlı komplikasyonlar zinciri. Ulusal Cer Derg 2014;30:173-5. [CrossRef]

7. Zaafouri H, Mrad S, Khedhiri N, Haddad D, Bouhafa A, Maamer AB. First experience with outpatient laparoscopic cholecystectomy in Tunisia. Pan Afr Med J 2017; 28:78. [CrossRef]

8. Hobbs MS, Mai Q, Knuiman MW, Fletcher DR, Ridout SC. Surgeon experience and trends in intraoperative complications in laparoscopic cholecystectomy. Br J Surg 2006;93:844-53.

9. Banz V, Gsponer T, Candinas D, Guller U. Population-based analysis of 4113 patients with acute cholecystitis: defining the optimal time-point for laparoscopic cholecystectomy. Ann Surg 2011;254:964-70. [CrossRef]

10. Bedirli A, Sözüer ME, Şakrak Ö, Güler İ, Arıtaş Y. Akut Kolesistitli Hastalarda Laparoskopik Kolesistektominin Güvenliği ve Etkinliği. End Lap Ve Minimal İnvaziv Cerrahi 2002;9:201-5.

11. Kiviluoto T, Siren J, Luukkonen P, Kivilaakso E. Randomised trial of laparoscopic versus open cholecystectomy for acute and gangrenous cholecystitis. Lancet 1998;351:321-5.

12. Tekin A, Küçükkartallar T, Belviranlı M, Vatansev $C$, Aksoy $F$, Tekin Ş, et al. Akut kolesistit için erken laparoskopik kolesistektomi. Ulusal Travma Acil Cerrahi Dergisi 2009;15:62-6.

13. Wu YV, Linehan DC. Bile duct injuries in the era of laparoscopic cholecystectomies. Surg Clin North Am 2010;90:787802. [CrossRef]

14. Bağcı S, Erçin CN, Tüzün A, Gülşen $M$, Uygun A, Balkan M, et al. Kolesistektomiye bağlı safra yolu yaralanmalarında endoskopik tanı ve tedavi. Gülhane Tıp Dergisi 2002;44:41522.

15. Gönültaş F, Yönder H, Sümer F. Laparoskopik Kolesistektomi Sırasında Oluşan Ana Safra Yolu Yaralanmasının Laparokopik Onarımı. CausaPedia 2015;4:1231.

16. Kohga A, Okumura T, Yamashita K, Isogaki J, Kawabe A, Kimura T. Does early surgery imply a critical risk for patients with Grade III acute cholecystitis? Asian J Endosc Surg 2020 Mar 23. [Epub ahead of print], doi: 10.1111/ases.12799.

17. Özaslan A, Özaslan İ, Yaycı N, Kalyoncu H. Ölümle Sonuçlanan 5 Laparoskopik Kolesistektomi. End Lap ve Minimal İıvaziv Cerrahi 2004;9:58-62.

18. Imanzadeh A, Kokabi N, Pourjabbar S, Latich I, Pollak J, $\mathrm{Kim} \mathrm{H}$, et al. Safety and Efficacy of Percutaneous Cholecystostomy for Emphysematous Cholecystitis. J Clin Imaging Sci 2020;10:9. [CrossRef]

19. Kirkegård J, Horn T, Christensen SD, Larsen LP, Knudsen AR, Mortensen FV. Percutaneous cholecystostomy is an effective definitive treatment option for acute acalculous cholecystitis. Scand J Surg 2015;104:238-43. [CrossRef]

20. Lunevicius R. Laparoscopic subtotal cholecystectomy: a classification, which encompasses the variants, technical modalities, and extent of resection of the gallbladder. Ann $\mathrm{R}$ Coll Surg Engl 2020;102:315-7. [CrossRef]

21. Purzner $\mathrm{RH}, \mathrm{Ho} K \mathrm{~B}, \mathrm{Al}-\mathrm{Sukhni} \mathrm{E}$, Jayaraman S. Safe laparoscopic subtotal cholecystectomy in the face of severe inflammation in the cystohepatic triangle: a retrospective review and proposed management strategy for the difficult gallbladder. Can J Surg 2019;62:402-11. [CrossRef] 